Brit. J. prev. soc. Med. (1968), 22, 132-137

\title{
PERINATAL MORTALITY IN WALES
}

\author{
BY \\ DAVID J. B. ASHLEY, M.D., M.C. PATH. \\ Consultant Pathologist, Morriston Hospital, Swansea
}

The death rate among infants in the last weeks of pregnancy and the first days of postnatal life has been decreasing steadily as the standards of antenatal and postnatal care have improved and as the general standard of health of the population has become better. There are still, however, regional differences in the risk of perinatal death, and in the Principality of Wales the risk of losing a child is greater than it is in England (Heady, Stevens, Daly, and Morris, 1955). Table I shows for the years 1958-63 the perinatal death rate (stillbirths plus deaths before 1 week per 1,000 live and stillbirths) and the death rates from congenital malformations, birth injury, asphyxia neonatorum, and immaturity for England and Wales as a whole and for Wales separately. Deaths from congenital malformations were related, as an approximation, to total births during this 6-year period as the majority of such deaths occur in early infancy. In each category, except that of birth injury, the rate in Wales was above that for England and Wales by 15 to 20 per cent.

TABLE I

PERINATAL DEATH RATES /1,000 BIRTHS, 1958-63

\begin{tabular}{|c|c|c|c|}
\hline \multicolumn{2}{|l|}{ Area } & $\begin{array}{c}\text { England } \\
\text { and } \\
\text { Wales }\end{array}$ & Wales \\
\hline Perinatal Deaths & & $32 \cdot 75$ & $38 \cdot 30$ \\
\hline Deaths from & $\begin{array}{l}\text { Congenital } \\
\text { Malformations } \\
\text { Birth Injury } \\
\text { Asphyxia } \\
\text { Immaturity }\end{array}$ & $\begin{array}{l}6 \cdot 30 \\
2 \cdot 33 \\
3 \cdot 24 \\
3 \cdot 60\end{array}$ & $\begin{array}{l}7 \cdot 20 \\
2 \cdot 44 \\
4 \cdot 52 \\
4 \cdot 21\end{array}$ \\
\hline
\end{tabular}

I have shown elsewhere (Ashley, 1966; Ashley and Davies, 1966a, b) that the population of Wales can be divided into a Welsh and a non-Welsh component and that differences in disease incidence between the two may be related to genetic factors, to differences in the gene pools of the Welsh population and the English population. The present paper $\omega$ reports an investigation which tests and disproves $\vec{\omega}$ the hypothesis that genetic factors of this type are $N$

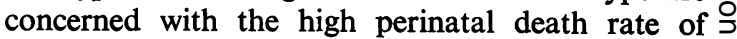
Wales and further investigations which suggest possible alternative hypotheses.

I. Major Local Authority Areas in Wales

The perinatal death rate and the death rates from congenital malformation, birth injury, neonataf asphyxia, and immaturity were calculated severally for the thirteen counties and four county boroughs of Wales for the years 1958-63 inclusive (Registrar General, 1960a, 1960b, 1962, 1963, 1964, 1965). The perinatal death rate was lower than that for England and Wales only in the case of the county of Merioneth.

The areas were divided into groups in four ways: according to the frequency with which the Welsh Language was used; geographically into North and South Wales; into coal mining and non-coal mining areas; and by the general socio-economic level of the population. The five rates were calculated within each grouping (Table II, opposite) and an analysis of variance was carried out on the data from the seventeen areas (Table III, opposite).

(a) Welshness.-The major local authority areas of Wales may be divided into three groups according to the frequency with which the Welsh of language is used in the population (General Register Office, 1962; Ashley and Davies, 1966b). In the high "Welsh" areas, the counties of Anglesey, Caernarvon, Cardigan, Carmarthen, and Merioneth, more than 70 per cent. of the population are Welshspeaking. In the intermediate areas, the counties of Brecon, Denbigh, Flint, Glamorgan, Montgomery, and Pembroke, and the County Boroughs of Merthyr Tydfil and Swansea, between 15 and 45 per 
TABLE II

PERINATAL DEATH RATES: REGIONS OF WALES, 1958-1963

\begin{tabular}{|c|c|c|c|c|c|c|}
\hline \multicolumn{2}{|c|}{ Factors Investigated } & $\begin{array}{l}\text { Perinatal } \\
\text { Deaths }\end{array}$ & $\begin{array}{c}\text { Congenital } \\
\text { Malformations }\end{array}$ & Birth Injury & $\begin{array}{l}\text { Neonatal } \\
\text { Asphyxia }\end{array}$ & Immaturity \\
\hline $\begin{array}{l}\text { Frequency of Welsh } \\
\text { Speaking }\end{array}$ & $\begin{array}{l}\text { High } \\
\text { Intermediate } \\
\text { Low }\end{array}$ & $\begin{array}{l}36 \cdot 0 \\
39 \cdot 0 \\
38 \cdot 0\end{array}$ & $\begin{array}{l}7 \cdot 10 \\
7 \cdot 40 \\
6 \cdot 90\end{array}$ & $\begin{array}{l}2 \cdot 26 \\
2 \cdot 56 \\
2 \cdot 29\end{array}$ & $\begin{array}{l}4 \cdot 05 \\
4 \cdot 48 \\
4 \cdot 98\end{array}$ & $\begin{array}{l}4 \cdot 34 \\
4 \cdot 05 \\
4 \cdot 42\end{array}$ \\
\hline $\begin{array}{l}\text { Geographical } \\
\text { Subdivision }\end{array}$ & $\begin{array}{l}\text { North } \\
\text { South }\end{array}$ & $\begin{array}{l}35 \cdot 0 \\
39 \cdot 2\end{array}$ & $\begin{array}{l}6 \cdot 47 \\
7 \cdot 38\end{array}$ & $\begin{array}{l}2 \cdot 32 \\
2 \cdot 47\end{array}$ & $\begin{array}{l}3 \cdot 86 \\
4 \cdot 63\end{array}$ & $\begin{array}{l}3 \cdot 37 \\
4 \cdot 41\end{array}$ \\
\hline Coal-Mining & $\begin{array}{l}\text { Coal-Mining Areas } \\
\text { Non-Coal-Mining } \\
\text { Areas }\end{array}$ & $\begin{array}{l}39 \cdot 8 \\
36 \cdot 2\end{array}$ & $\begin{array}{l}7 \cdot 52 \\
6 \cdot 75\end{array}$ & $\begin{array}{l}2 \cdot 41 \\
2 \cdot 48\end{array}$ & $\begin{array}{l}4 \cdot 62 \\
4 \cdot 36\end{array}$ & $\begin{array}{l}4 \cdot 31 \\
4 \cdot 06\end{array}$ \\
\hline $\begin{array}{l}\text { Socio-Economic } \\
\text { Index }\end{array}$ & $\begin{array}{r}<250 \\
251-290 \\
>290\end{array}$ & $\begin{array}{l}35 \cdot 0 \\
37 \cdot 1 \\
40 \cdot 1\end{array}$ & $\begin{array}{l}6 \cdot 17 \\
7 \cdot 23 \\
7 \cdot 55\end{array}$ & $\begin{array}{l}2 \cdot 44 \\
2 \cdot 40 \\
2 \cdot 47\end{array}$ & $\begin{array}{l}5 \cdot 49 \\
3 \cdot 68 \\
4 \cdot 83\end{array}$ & $\begin{array}{l}3 \cdot 31 \\
4 \cdot 62 \\
4 \cdot 24\end{array}$ \\
\hline
\end{tabular}

TABLE III

MAJOR LOCAL AUTHORITY AREAS OF WALES ANALYSIS OF VARIANCE: LEVELS OF SIGNIFICANCE

\begin{tabular}{|c|c|c|c|c|c|}
\hline Factors Investigated & Perinatal Deaths & $\begin{array}{c}\text { Congenital } \\
\text { Malformations }\end{array}$ & Birth Injury & Neonatal Asphyxia & Immaturity \\
\hline $\begin{array}{l}\text { "Welshness" } \\
\text { North/South } \\
\text { Coal-Mining } \\
\text { Socio-Economic } \\
\text { Index }\end{array}$ & $\begin{array}{l}\quad \mathrm{N} / \mathrm{S} \\
1 \text { per cent. } \\
1 \text { per cent. } \\
1 \text { per cent. }\end{array}$ & $\begin{array}{c}\mathrm{N} / \mathrm{S} \\
1 \text { per cent. } \\
\mathrm{N} / \mathrm{S} \\
5 \text { per cent. }\end{array}$ & $\begin{array}{l}\mathbf{N} / \mathbf{S} \\
\mathbf{N} / \mathbf{S} \\
\mathbf{N} / \mathbf{S} \\
\mathbf{N} / \mathbf{S}\end{array}$ & $\begin{array}{c}\mathbf{N} / \mathbf{S} \\
\mathbf{N} / \mathrm{S} \\
1 \text { per cent. } \\
1 \text { per cent. }\end{array}$ & $\begin{array}{c}\mathbf{N} / \mathbf{S} \\
5 \text { per cent. } \\
\mathbf{N} / \mathbf{S} \\
N / S\end{array}$ \\
\hline
\end{tabular}

$\mathbf{N} / \mathbf{S}=$ Not Significant.

cent. of the population are Welsh-speaking. In the low "Welsh" areas, the counties of Monmouth and Radnor and the County Boroughs of Cardiff and Newport, less than 10 per cent. of the population are Welsh-speaking. The rates for these three subdivisions of Wales are shown in Table II. In no instance is there a pattern of rates highest in the high "Welsh" areas and lowest in the low "Welsh" areas. Indeed the only gradation seen is in death from neonatal asphyxia, in this case the highest death rate is seen in the area which is least "Welsh".

In no instance is the effect of "Welshness" significant (Table III).

(b) The North/South Difference.-Separation of the Principality into North and South shows a more favourable experience in the North in each instance (Table II). This difference is significant in the cases of perinatal death, congenital malformation, and immaturity (Table III). There are marked environmental differences between North Wales, which is predominantly rural in character, and South Wales, which is predominantly urban.

(c) Coal Mining.-Sketch maps of the distribution of perinatal mortality in Wales showed an apparent excess in the industrial mining areas of South Wales.
The Local Authority areas were therefore divided into those in which more than 5 per cent. of the working male population was employed in the coalmining industry and those in which this was not the case (General Register Office, 1956). The perinatal death rate and the death rate from neonatal asphyxia were significantly higher in the areas in which coalmining was an important industry (Tables II, III).

(d) Social Class.-Previous studies by other workers (Morris and Heady, 1955; Kincaid, 1965) have shown clearly that the perinatal deaths are more likely to occur in the children of members of the lower social classes than in Social Classes I and II. For the purposes of this investigation an index of the proportion of members of the lower social classes was extracted from the Registrar General's Socio-Economic Group Tables (General Register Office, 1965). The proportion of men in the working population in his classes 10 (semi-skilled manual workers), 11 (unskilled manual workers), and 15 (agricultural workers) was summed for each of the local authority areas, and Wales was divided into three groups: areas in which the Socio-Economic Index was less than 250 , areas in which it was between 251 and 290, and areas in which it was greater than 290 per 1,000 economically active males. This index 
was preferred because, in general, children are born to economically active fathers and because it could easily be calculated for the areas falling into the three socio-economic groups (Table II). There was a gradation of rates corresponding to the gradation of groups in the case of perinatal mortality and deaths from congenital malformations. Differences in socio-economic status contributed significantly to the variance in the seventeen areas in the cases of perinatal mortality, congential malformation, and neonatal asphyxia.

The perinatal death rate is strongly correlated with the socio-economic level of the population (see also Section III). Allowance for this factor was made by the use of a regression equation and a "Standardized Mortality Ratio" (SMR) for the perinatal period was determined for the three different areas in respect of Welsh-speaking and for the areas which were and were not centres of the mining industry. This SMR for the whole Principality was 108 , as was that for each of the areas of high, intermediate, and low Welsh speaking. The SMR for the coal mining areas was 111 while that for the non-mining areas was 103; these two values differ significantly.

\section{The Small Local Authority Areas of Brecon, Carmarthen, Glamorgan, and Monmouth}

In an attempt to separate the general effects of socio-economic status and the special effect of coalmining, an analysis was made of data from the 57 smaller local authority areas which make up the industrial South Wales counties of Brecon, Carmarthen, Glamorgan, and Monmouth. There was a strongly positive correlation $(r=+0.656)$ between the perinatal death rate and the Socio-Economic Index as defined above.

The effect of socio-economic status was removed by applying a regression formula to the data and an analysis of variance was then carried out on the deviations from the expected perinatal death rate (Table IV).

TABLE IV

PERINATAL MORTALITY

ANALYSIS OF VARIANCE: SMALL LOCAL AUTHORITY AREAS AFTER REGRESSION

\begin{tabular}{l|rrcc}
\hline Factors Investigated & d.f. & s.s. & mean s.s. & F \\
\hline Coal-mining, & 1 & $90 \cdot 3$ & $90 \cdot 3$ & $3 \cdot 42$ \\
"Welshness" & 2 & $66 \cdot 6$ & $33 \cdot 3$ & $1 \cdot 26$ \\
Urban/Rural & 1 & $136 \cdot 5$ & 136 & $5 \cdot 15$ \\
Residual & 52 & $1375 \cdot 5$ & $26 \cdot 4$ & \\
\hline \multicolumn{1}{c}{ Total } & 56 & $1668 \cdot 4$ & & \\
\hline
\end{tabular}

A significant contribution to the variance was? made by town dwelling as opposed to countryz dwelling. The contribution of Welshness was very small. The contribution of coal-mining was larger but did not reach statistical significance.

11I. The Counties and County Boroughs of $\frac{\overline{\bar{p}}}{\sqrt{\frac{\pi}{2}}}$
England and Wales

The mean perinatal death rates for the county@ boroughs and counties of England and Wales, exclud- ing the administrative county of London and the ${ }_{-}^{\circ}$ five minute counties of Ely, Peterborough, Rutland, $\vec{\omega}$ the Isle of Wight, and Radnor, were extracted for the period 1962-64 from the Registrar General's annual tables (Registrar General, 1964, 1965, 1966) and were correlated with the Socio-Economic Index N used previously. The correlation coefficients of the $\omega$ relation between the perinatal death rate and the $\vec{N}$ Socio-Economic Index was +0.402 in the case of 0 the 85 county boroughs and +0.643 in the case of the 56 counties. Both these values are significant at $\vec{c}$ the 1 per cent. level.

Regression equations were calculated separately $\vec{\varphi}$ for the county boroughs and for the counties, arfi $\infty$ the deviation of the observed rates from the expectil. rates was determined. In the case of 22 Coundy Boroughs and nine counties the observed rate w more than 10 per cent. higher than the expected rate, in the case of eleven County Boroughs and $\frac{\mathscr{Q}}{\Phi}$ three counties it was between 5 and 10 per cent. $\varrho$ higher than the expected rate. Thirteen county $\overrightarrow{\overrightarrow{0}}$ boroughs and six counties had observed rates more 3 than 10 per cent. below the expected rate and a further thirteen county boroughs and twelve counties? had observed rates between 5 and 10 per cent. lower $\bar{D}$ than the expected rates (Tables V and VI, opposite). ?

Areas with high rates, both county boroughs and $\frac{\sigma}{3}$ counties, tended to be situated in the north and west of the country while those with low rates tended to 0 ? be in the south and east. A striking feature was that

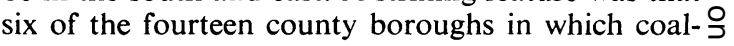
mining was an important industry and five of the $>$ thirteen counties in which mining was prominent (Ashley and Davies, 1966c) had high perinatal death $N$ rates, whereas none of the mining counties or countyboroughs had low perinatal mortality rates.

An analysis of variance for the data from the $85 \mathrm{~N}$ county boroughs studied after correction for socioeconomic status shows that a significant part of the variance was associated with the coal-mining industry (Table VII, opposite).

It was considered possible that the association $\frac{0}{0}$ with coal-mining in the counties might simply be a 
TABLE V

DEVIATIONS FROM EXPECTED PERINATAL DEATH RATE COUNTY BOROUGHS AFTER REGRESSION BASED ON SOCIO-ECONOMIC INDEX

\begin{tabular}{|c|c|c|c|}
\hline \multicolumn{2}{|c|}{ High } & \multicolumn{2}{|c|}{ Low } \\
\hline$>10$ per cent. & $>5$ per cent. & $>5$ per cent. & $>10$ per cent. \\
\hline $\begin{array}{l}\text { Birkenhead } \\
\text { Chester } \\
\text { Stockport } \\
\text { Wallasey } \\
\text { Carlisle }\end{array}$ & $\begin{array}{l}\text { South Shields } \\
\text { Cardiff } \\
\text { Swansea } \\
\text { Newcastle } \\
\text { Wolver- }\end{array}$ & $\begin{array}{l}\text { East Ham } \\
\text { Southend } \\
\text { West Ham } \\
\text { Canterbury } \\
\text { Bolton }\end{array}$ & $\begin{array}{l}\text { Luton } \\
\text { Plymouth } \\
\text { Bristol } \\
\text { Bootle } \\
\text { Grimsby }\end{array}$ \\
\hline Sunderland & & & Great \\
\hline $\begin{array}{l}\text { Blackburn } \\
\text { Blackpool }\end{array}$ & $\begin{array}{l}\text { Dewsbury } \\
\text { Huddersfield }\end{array}$ & $\begin{array}{l}\text { Tynemouth } \\
\text { West }\end{array}$ & $\begin{array}{l}\text { Norwich } \\
\text { Northampton }\end{array}$ \\
\hline $\begin{array}{l}\text { Burnley } \\
\text { Manchester } \\
\text { St. Helens } \\
\text { Salford } \\
\text { Lincoln } \\
\text { Bath } \\
\text { Smethwick } \\
\text { Walsall } \\
\text { Dudley } \\
\text { Doncaster } \\
\text { Hull } \\
\text { Merthyr Tydfil } \\
\text { Portsmouth } \\
\text { Southport }\end{array}$ & $\begin{array}{l}\text { Leeds } \\
\text { Rotherham } \\
\text { Eastbourne }\end{array}$ & $\begin{array}{l}\text { Croydon } \\
\text { Solihull } \\
\text { Worcester } \\
\text { Halifax } \\
\text { York }\end{array}$ & $\begin{array}{l}\text { Oxford } \\
\text { Ipswich } \\
\text { Brighton } \\
\text { Hastings } \\
\text { Sheffield }\end{array}$ \\
\hline
\end{tabular}

TABLE VI

DEVIATIONS FROM EXPECTED PERINATAL DEATH RATE COUNTIES AFTER REGRESSION BASED ON SOCIOECONOMIC INDEX

\begin{tabular}{|c|c|c|c|}
\hline \multicolumn{2}{|c|}{ High } & \multicolumn{2}{|c|}{ Low } \\
\hline$>10$ per cent. & $>5$ per cent. & $>5$ per cent. & $>10$ per cent. \\
\hline $\begin{array}{l}\text { Cornwall } \\
\text { Lancashire } \\
\text { Westmorland } \\
\text { Brecon } \\
\text { Cardigan } \\
\text { Carmarthen } \\
\text { Glamorgan } \\
\text { Monmouth } \\
\text { Pembroke }\end{array}$ & $\begin{array}{l}\text { Stafford } \\
\text { Wiltshire } \\
\text { Flint }\end{array}$ & $\begin{array}{l}\text { Bedford } \\
\text { Berkshire } \\
\text { Devon } \\
\text { Gloucester } \\
\text { Hampshire } \\
\text { Hertford } \\
\text { Lincoln } \\
\text { (Kesteven) } \\
\text { Northampton } \\
\text { Somerset } \\
\text { Suffolk E. } \\
\text { Sussex E. } \\
\text { Caernarvon }\end{array}$ & $\begin{array}{l}\text { Cambridge } \\
\text { Huntingdon } \\
\text { Norfolk } \\
\text { Oxford } \\
\text { Yorkshire E. } \\
\text { Merioneth }\end{array}$ \\
\hline
\end{tabular}

TABLE VII

ANALYSIS OF VARIANCE COUNTY BOROUGHS AFTER REGRESSION

\begin{tabular}{l|rrcc}
\hline Factors Investigated & d.f. & s.s. & mean s.s. & F \\
\hline $\begin{array}{l}\text { Coal-mining } \\
\text { Residual }\end{array}$ & 83 & 61 & 61 & $4 \cdot 26$ \\
\hline Total & 84 & 1,247 & & \\
\hline
\end{tabular}

reflection of the generally industrial nature of these counties. An analysis of variance was therefore done using as parameters whether or not coalmining was an important industry and also a rough index of whether or not the county was an industrial area; for this purpose the proportion of economically active men in the Registrar General's group 9 (skilled manual workers) was used $(<250 / 00$, 251-320/00, >321/00). The analysis (Table VIII) shows that a significant part of the variance was related to coal-mining but that the industrial or nonindustrial nature of the county was without significant effect.

TABLE VIII

ANALYSIS OF VARIANCE COUNTIES AFTER REGRESSION

\begin{tabular}{l|cccc}
\hline Factors Investigated & d.f. & s.s. & mean s.s. & F \\
\hline $\begin{array}{l}\text { Coal-mining } \\
\text { Industrial/ } \\
\text { Not Industrial } \\
\text { Residual }\end{array}$ & 1 & 35 & 35 & $4 \cdot 22$ \\
\hline \multicolumn{1}{c}{ Total } & 52 & $431 \cdot 2$ & $3 \cdot 5$ & $<1$ \\
\hline
\end{tabular}

The types of coal mined in England and Wales can be roughly classified as hard and soft. The hard coals, steam coal and anthracite, being found in the South Wales coalfield and in the northern coalfields of Northumberland, Durham, Lancashire, and the West Riding of Yorkshire, while the soft coal is mined principally in the Midlands and in North Wales. Taking the mining areas alone, it was found (Table IX) that there was a significantly higher perinatal death rate in the hard coal areas than in those in which the coal was of the soft variety.

TABLE IX

ANALYSIS OF VARIANCE

COAL-MINING TOWNS AND COUNTIES AFTER REGRESSION

\begin{tabular}{c|cccc}
\hline Factors Investigated & d.f. & s.s. & mean s.s. & F \\
\hline $\begin{array}{c}\text { Hard/Soft Coal } \\
\text { Residual }\end{array}$ & $\begin{array}{c}1 \\
25\end{array}$ & $\begin{array}{c}47 \cdot 2 \\
124\end{array}$ & $\begin{array}{c}47 \cdot 2 \\
4 \cdot 96\end{array}$ & $9 \cdot 5$ \\
\hline Total & 26 & $171 \cdot 2$ & & \\
\hline
\end{tabular}

\section{Discussion}

The data presented in this paper again confirm the strong association between perinatal mortality and low social class or socio-economic status (Morris and Heady, 1955; Kincaid, 1965). The observed geographical disparities in perinatal mortality experience cannot, however, be explained simply on this basis. When allowance is made for the proportions of members of the lower socio-economic groups, there are still many areas in which the perinatal mortality rate is as much as 10 per cent. higher or lower than might have been expected. 
Analysis of the perinatal mortality of the various parts of Wales excludes the hypothesis that the high perinatal mortality in the Principality might be genetic in origin and related to the different gene pools of the Welsh and non-Welsh people of Wales. Consideration of those parts of Wales in which there is the highest perinatal mortality indicate that there is an unfavourable experience in the industrial south-east of the country and especially in the areas in which coal-mining is the predominant industry.

Consideration of the components of perinatal mortality shows an association between socioeconomic status and the frequency of congenital malformation and of neonatal asphyxia, an association between coal-mining and neonatal asphyxia, and a higher frequency of congenital malformation and of immaturity in South Wales than in North Wales.

It is thought unlikely that the North/South differences are purely geographical in nature, although the different geological formations upon which the people of North and South Wales live may be relevant factors, but rather that the generally poorer experience of the people of South Wales is related to the lower socio-economic status in South Wales and to the presence in that part of the country of the coal-mining industry.

An analysis of the mean perinatal mortality rates for the counties and county boroughs of England and Wales again shows an association between coalmining and a high perinatal mortality rate. This association is statistically significant. In the case of the counties of England and Wales, it was shown that there was no significant association with industrialization per se but that the high perinatal mortality was to be seen specifically in connexion with this industry.

Any statistical association must be susceptible to rational scientific explanation or it is without value. What then is the rationale of the high perinatal mortality of these mining areas? Kincaid (1965), discussing the association of high neonatal mortality with low social class, suggested that relevant factors might be: poor attendance at antenatal clinics and hence poor antenatal care, a high pre-nuptial conception rate with a lower average age of mothers at the time of pregnancy, the high frequency with which the mother of low socio-economic status has to continue working during pregnancy, and possibly the effect of poor social and nutritional conditions during the childhood and adolescence of the mother herself. During the depression of the 1930s the mining areas were among the worst hit of all in the country, and Kincaid's last suggested explanation could well be true for women born and growing up during that era. Such women would, however, now be of or over
30 years of age, while the majority of patients in the maternity wards are below this age and were born during or, indeed, after the second world war when the standards of nutrition were much improved. The Welsh excess of perinatal deaths is still relatively as great as it was 15 years ago when the majority of mothers had been born and brought up in the economic depression.

A second possible explanation is that the relevant factors are geological and are related either to specific effects of coal and coal-dust on the men who are exposed to it all day and on the women and children whose lives are dominated by the everpresent piles of colliery waste and the all-pervading dust. If this is the case, investigation of environmental factors in the coal fields is called for; there may for example be an excess of terrestrial radioactivity in such areas and, since the perinatal mortality experience of the soft coal fields of the Midlands does not differ from that of the rest of the country, an environmental comparison of the two types of coal field might be useful. Environmental difference in respect of the causation of pneumoconiosis (Meiklejohn, 1960) and the relative frequency of bronchitis and lung cancer (Ashley and 8 Davies, 1966c) have been observed although it is a far cry from inhaled dust to foetal mortality.

Alternatively, the differences may be due to more general geological phenomena, the coal measures lie in limestone strata and the high perinatal mortality of a district such as the Gower Peninsula or the County of Pembroke where limestone is abundant but coal measures are not to be found may be due to this cause. Correlation of perinatal mortality with geological formations is a possible method by which this hypothesis could be tested.

This paper makes no claim to be exhaustive. One hypothesis, that the high perinatal mortality of Wales is genetic in origin has been disproved. The association of higher perinatal mortality with low socioeconomic status has again been supported. Apart from this there remain differences in the perinatal mortality experience of different parts of the country which cannot be explained on a simple economic basis. One environmental explanation, that high perinatal mortality is specifically related to the coal-mining industry whether the association is due specifically to coal or to more general geological factors is discussed. Without doubt there are more such associations to be examined and tested.

SUMmary

Data concerning the perinatal mortality in England and Wales have been collected and examined. 
The association between high perinatal mortality and low socio-economic status has been confirmed.

The hypothesis that the high perinatal mortality in Wales is related to genetic factors found in the Welsh rather than the non-Welsh has been examined and rejected.

After the effect of socio-economic status has been removed by the use of regression equations, an excess of perinatal mortality is seen in the North and West of the country. It is suggested that, in part, this is due to some specific factor or factors associated with the coal-mining industry.

An appeal is made for further detailed investigation of environmental differences and their association with differences in perinatal mortality.

This work was carried out with the aid of a research grant from the Welsh Hospital Board.

\section{REFERENCES}

Ashley, D. J. B. (1966). Brit. J. Urol., 38, 567 (Observations on the epidemiology of prostatic hyperplasia in Wales.

and Davies, H. D. (1966a). Gut, 7, 542 (Gastric cancer in Wales).

(1966b). J. med. Genet., 3, 203 (The use of the surname as a genetic marker in Wales). (1966c). Brit.J. prev. soc. Med., 20, 148 (Lung cancer and chronic bronchitis in Wales).

General Register Office (1956). "Census 1951 England and Wales", Occupation Tables. H.M.S.O., London.

_ (1962). "Census 1951. Wales. Report on Welshspeaking Population." H.M.S.O., London.

(1965). "Census 1961. England and Wales. Occupation Industry. Socio-Economic Groups." H.M.S.O., London.

Heady, J. A., Stevens, C. F., Daly, C., and Morris, J. N. (1955). Lancet, 1, 499 (Social and biological factors in infant mortality. IV. The independent effects of social class, region, the mother's age and her parity).

Kincaid, J. C. (1965). Brit. med. J., 1, 1057 (Social pathology of foetal and infant loss).

Meiklejohn, A. (1960). In "Industrial Pulmonary Diseases", ed. E. J. King and C. M. Fletcher, p.1. (Churchill), London.

Morris, J. N., and Heady, J. A. (1955). Lancet, 1, 554 (Social and biological factors in infant mortality. V. Mortality in relation to the father's occupation, 19111950).

Registrar General (1960a). Statistical Review of England and Wales for the Year 1958", Part I. Tables Medical. H.M.S.O., London. (1960b). Idem, 1959. - (1962). Idem, 1960. (1963). Idem, 1961. (1964). Idem, 1962. (1965). Idem, 1963. (1966). Idem, 1964. 